\title{
Development, growth and metabolic rate of Hermetia illucens larvae
}

Gligorescu, Anton; Toft, Søren; Hauggaard-Nielsen, Henrik; Axelsen, Jørgen Aagaard; Nielsen, Søren Achim

Published in:

Journal of Applied Entomology

DOI:

10.1111/jen.12653

Publication date:

2019

Document Version

Peer reviewed version

Citation for published version (APA):

Gligorescu, A., Toft, S., Hauggaard-Nielsen, H., Axelsen, J. A., \& Nielsen, S. A. (2019). Development, growth and metabolic rate of Hermetia illucens larvae. Journal of Applied Entomology, 143(8), 875-881. [143]. https://doi.org/10.1111/jen.12653

\section{General rights}

Copyright and moral rights for the publications made accessible in the public portal are retained by the authors and/or other copyright owners and it is a condition of accessing publications that users recognise and abide by the legal requirements associated with these rights.

- Users may download and print one copy of any publication from the public portal for the purpose of private study or research.

- You may not further distribute the material or use it for any profit-making activity or commercial gain.

- You may freely distribute the URL identifying the publication in the public portal.

\section{Take down policy}

If you believe that this document breaches copyright please contact rucforsk@kb.dk providing details, and we will remove access to the work immediately and investigate your claim. 
ORIGINAL CONTRIBUTION

\section{Development, growth and metabolic rate of Hermetia illucens larvae}

Anton Gligorescu, 1,2

Søren Toft, 3

Henrik Hauggaard-Nielsen, 4

Jørgen A. Axelsen, 5

Søren Achim Nielsen, 1, $\square$

Emailsan@ruc.dk

AQ1

$\mathrm{AQ} 2$

1 Department of Science and Environment, Roskilde University, Roskilde, Denmark

2 Danish Technological Institute, Aarhus C, Denmark

3 Department of Bioscience, Aarhus University, Århus C, Denmark

4 Department of People and Technology, Roskilde University, Roskilde, Denmark

5 Department of Bioscience - Plant and Insect Ecology, Aarhus University, Silkeborg, Denmarl AQ3

\section{Correspondence}

Søren Achim Nielsen, Department of Science and Environment, Roskilde University, Universitetsvej 1, Bldg. 12.2, 4000 Roskilde, Denmark.

Email: san@ruc.dk

\section{INTRODUCTION}

The human population is expected to reach 9.1 billion by the year 2050, and at the same time, animal production is expected to rise, leading to an increasing requirement for protein-rich fodder sources in the animal production sector (FAO, 2009; Speedy, 2004). Denmark is an important factor in the animal production sector in the EU with a total share of $7.2 \%$ of the estimated $22 \mathrm{Mt}$ of pork meat production in the EU in 2013 (Eurostat, 2016). The trend of an increasing human population with an associated increase in animal and meat production will subsequently lead to an increasing need for protein sources in order to secure animal feed (Speedy, 2004). Insect bioconversion of organic waste streams could provide a solution to these challenges by successfully 
recirculating viable nutrients and energy that would otherwise be wasted, while providing a more sustainable protein source and thus contributing to food security (van Huis et al., 2013). Thus, insect bioconversion can improve the environmental footprint of vertebrate meats indirectly, through their use as feed. Rearing insects on human inedible wastes and feeding them to larger food animals can boost the protein content of many of these animals and is more environmentally friendly and efficient than growing fields of grains or other feeds, which use land and resources that could otherwise be used to grow food for humans. Among the most promising insect, species to be used as protein source for animal feed is Hermetia illucens (Linnaeus, 1758) (Diptera: Stratiomyidae), also known as the black soldier fly (Barragan-Fonseca, Dicke, \& vanLoon, 2017).

$\mathrm{AQ} 4$

Hermetia illucens is an American native insect but now has a worldwide distribution, occupying habitats between $45^{\circ} \mathrm{N}$ and $40^{\circ} \mathrm{S}$. In Europe, the species was first recorded in Malta in 1926 and it currently inhabits mainly the Mediterranean area (Marshall, Woodley, \& Hauser, 2015). However, it has been found as far north as the Czech Republic (Roháček \& Hora, 2013). The species has three generations per year in subtropical regions and one generation per year in temperate regions (Benelli, Canale, Raspi, \& Fornaciari, 2014; Sheppard, Newton, Thompson, \& Savage, 1994). The adult flies only serve reproductive purposes and live about 8-20 days depending on temperature, sex, larval food quality and larval development time (Gobbi, Martinez-Sanchez, \& Rojo, 2013; Tomberlin, Adler, \& Myers, 2009; Tomberlin, Sheppard, \& Joyce, 2002). Mating occurs two days after metamorphosis, and the females oviposit about 500 eggs throughout their lifetime at the edge of decomposing substrates (Diclaro \& Kaufman, 2009). H. illucens larvae live in organic debris and have a short development time of about 20 days at $27^{\circ} \mathrm{C}$ before migrating into dry areas such as ground vegetation, where they pupate for about 18 days (Diclaro \& Kaufman, 2009; Tomberlin et al., 2009).

The larvae of $H$. illucens are scavengers able to feed on a wide range of organic substrates, including municipal organic waste, manure, food waste and human faeces, making them highly suitable for waste management (Diener, Zurbrugg, \& Tockner, 2009; Lalander, Fidjeland, Diener, Eriksson, \& Vinnerås, 2015; Newton, Sheppard, Watson, Burtle, \& Dove, 2005; Nguyen, Tomberlin, \& Van Laerhoven, 2013). Furthermore, the larvae of $H$. illucens contain highly valuable proteins and lipids, suitable to be used as feedstuff in aquaculture, poultry and in the swine industry (Magalhães et al., 2017; Cummins et al., 2017; St-Hilaire et al., 2007; Hale, 1973 cited by Newton et al., 2005; Newton, Booram, Barker, \& Hale, 1977).

Past studies mainly focused on the ability of using $H$. illucens larvae for organic waste management or as feedstuff, whereas only few scientific studies describe development and growth of the larvae (Kim et al., 2010; May, 1961; Oliveira, Doelle, \& Smith, 2016; Pujol-Luz, Pitaluga De Godoi, \& Barros-Cordeiro, 2016; 
Schremmer, 1986). Disturbingly, different numbers of larval stadia are reported in these papers. Thus, May (1961) and Kim et al. (2010) claim there are 6 larval stadia while Schremmer (1986) reports seven larval stadia. Furthermore, no literature was found to deal with the metabolic rate of different $H$. illucens larval instars.

Investigation of development, growth and metabolism of different larval instars could lead to a better understanding of larval performance and could further be used to optimize $H$. illucens bioconversion systems that aim to convert organic waste streams into larval biomass. In this work, some important parameters for understanding the life cycle, growth and metabolism were investigated. An important goal was to definitively determine the number of larval stadia through measurements of head capsules and microscopic observation of a moult between the 6 th and the 7 th larval stadia.

\section{MATERIAL AND METHODS}

\subsection{Insect rearing and abiotic factors recorded}

The stock of black soldier flies was provided by Dansk Insekt Protein ApS, Skjern, Denmark, and a colony was established at Roskilde University. The adult black soldier flies were bred in a wooden frame cage $(100 \times 63 \times 110 \mathrm{~cm})$ covered with mosquito net and maintained in a climate room at Roskilde University on a 14-: 10-hr light/dark regime at $26 \pm 1{ }^{\circ} \mathrm{C}$ and $27 \%$ relative humidity. The adult flies were provided with water and sugar during their entire life, and $2 \mathrm{~cm}$ diameter rolls of corrugated cardboard were placed in the cage as oviposition substrate. The cardboard rolls were checked and replaced daily in order to ensure that all eggs were oviposited within 24-hr intervals. This secured a relatively synchronized development of the larvae during the experiment. Eggs from the same corrugated cardboard were transferred to a transparent plastic box $(11 \times 11 \times 6 \mathrm{~cm})$ containing moist wadding. The plastic box was placed in front of a LED panel used as light source for the colony until egg eclosion was observed about four days later. About 500 neonate larvae were transferred to a plastic box $(17 \times 14 \times 11 \mathrm{~cm})$ covered with a plastic lid; holes of one $\mathrm{mm}$ were made in the lid in order to ensure air circulation. The larvae were reared on $100 \mathrm{~g}$ pulverized Gainesville medium $(50 \%$ wheat bran, $30 \%$ alfalfa hay and $20 \%$ maize mixed with water at a ratio of $10 \mathrm{~g}$ medium to $17 \mathrm{ml}$ water $(70 \%$ moisture) according to Tomberlin et al. (2002)). New freshly made medium was added to the plastic box every other day, until more than $50 \%$ of the larvae had reached the non-feeding (pre-pupal) stadium, distinguished by its dark brown colour, about 17 days later. This feeding strategy was adapted in order to minimize the handling effect on larval development (Nguyen et al., 2013). We consider that the daily addition of fresh medium and the daily removal of larvae as they grew larger would minimize the effects of scramble competition on larval growth.

The temperatures at the surface of the medium in the larval rearing box (mean $26.4 \pm 0.7^{\circ} \mathrm{C}$ ) were recorded every 5 min using a Hobo ${ }^{\circledR}$ U23 Pro v2 data logger (Onset ${ }^{\circledR}$ Computer Corporation). 


\subsection{Larval measurements}

Once egg eclosion had occurred, 10 larvae were randomly sampled daily for 18 days. The larvae were weighed and preserved in $70 \%$ ethanol for $24 \mathrm{hr}$ before the width of their head capsule (mm) was measured. As in May (1960) and Kim et al. (2010), the first six larval instars were distinguished based on the head capsule measurements. From previous studies of larval development in the black soldier fly (May, 1960; Kim et al., 2010; Schremmer, 1986), it is assumed that a change in head capsule width indicates a moult and that all early moults (i.e., prior to the moult between the 6th and 7th stadia; see below) lead to an increase in head capsule width. The larvae collected during the first 4 days of the experiment were weighed using a four decimals after milligram electronic scale (Mettler Toledo XP6; Mettler-Toledo A/S), and hereafter, the larvae were weighed using the four decimals after grams electronic scale (Mettler AE 163). Furthermore, the head capsule measurements of the larvae collected during the first three experimental days were measured using the Cell D 3.4 software connected to a compound microscope (Olympus CX41), and hereafter, the head capsules of elder larvae were measured by Cell D 3.4 software connected to a stereo microscope (Olympus SZ61). In addition to the daily head capsule measurements used to identify the actively feeding instars, ten 6th instars that showed signs of beginning ecdysis were placed in $70 \%$ ethanol for $24 \mathrm{hr}$. Based on these, the possible presence of a 7th instar larva inside the exuvia of the 6th instar larva, as claimed by Schremmer (1986), was observed under a stereomicroscope. Furthermore, the differences in morphological characteristics of the head capsules between the 6th and 7th instar larvae were assessed. The head capsules of 6th and 7th instar larvae and the ecdysis situation between the two stadia were inspected in a drop of Euparal (Carl RothGmbH+ Co) and photographed using Cell D 3.4 software connected to a stereo microscope (Olympus SZ61) equipped with a SC30 camera. AQ5

\subsection{Specific metabolic rate measurements}

The investigations of the metabolic rate consisted of measurements of the heat release from $\mathrm{H}$. illucens larvae under isothermal conditions at $27^{\circ} \mathrm{C}$ by using the calorimeter DSC-7707 (Hart Scientific, Pleasant Grove, UT; Nielsen, Jensen, Kristensen, \& Westh, 2006). Due to the small size of first and second instars, the metabolic rate of these was not measured. Thus, the specific metabolic rates of 3 rd, 4th and 5th instars $(n=9$ of each), 6th instars $(n=4)$ and the 7 th instars $(n=9)$ were measured.

The calorimeter had four removable steel ampoules $\left(1 \mathrm{~cm}^{3}\right)$ which were sealed with a threaded lid and closed with a gasket prior to the heat release measurements. One of the four ampoules was kept empty and used as a thermal reference, while the other three were employed in individual measurements of larval heat release. At the start of each experiment day, a blind measurement was performed on each of the three ampoules ( $\mathrm{H} 1, \mathrm{H} 2$ and $\mathrm{H} 3)$. After that the heat release data from these ampoules were plotted in a graph and visually checked. 
This was done in order to identify the data points at which thermodynamic equilibrium was achieved. Based on these data points, an average value of the blind measurements (AVG blind in $\mu \mathrm{W}$ ) was calculated for each ampoule.

The larvae belonging to different stadia were sampled from the medium and transferred gently and quickly into individual ampoules. These were hermetically closed and transferred to the calorimeter. The heat release was recorded every $30 \mathrm{~s}$ on all three ampoule samples for $1 \mathrm{hr}$. After this step, the data were plotted into a graph and visually inspected for reaching a plateau (thermal equilibrium); an average value of the heat release at the plateau for the individual larva (AVG heat in $\mu \mathrm{W}$ ) was subsequently calculated. Furthermore, the tested larvae were weighed and their wet weight (WW in $\mathrm{mg}$ ) was noted. After this, the AVG blind was subtracted from the calculated AVG heat, multiplied with -1 and divided by the WW of each individual larva, in order to estimate the specific metabolic rate (SMR in $\mu \mathrm{W} / \mathrm{mg}$ ), according to the Equation 1 .

$$
\mathrm{SMR}=\frac{(\text { AVG heat }- \text { AVG blind }) *-1}{\mathrm{WW}}
$$

\subsection{Statistics}

The statistics were performed using the IBM SPSS software ver. 24 (IBM Corp). The daily head capsule data as well as the SMR and the body mass of different instars were tested using a general linear model (GLM) for statistical significance $(\alpha=0.05)$, followed by Tukey's post hoc test for multiple comparisons. The data on SMR and body mass of different instars were square root transformed in order to ensure homogeneity of variance (Levene's test).

\section{RESULTS}

The controlled age of eggs used to start the larval culture secured a synchronized development of the larvae. With very few exceptions, all 10 larvae collected on the same day clearly were the same instar according to the head capsule measurements (Figure 1). Thus, one individual on day 2 and one on day 4 could be either instar 2 or instar 3; also, one individual on each of days 5, 6 and 7 could be either instar 4 or instar 5. Overall, the head capsule widths were found to increase stepwise, showing that $H$. illucens larvae pass through six stadia with significantly different head capsule widths $\left(F_{16}=480.1, p<0.001\right.$; Figure 1$)$. The larvae fed actively during these first six stadia. After day 15, the larvae turned darker brown in colour, stopped eating and started to migrate out of the substrate ("Wanderlarven" of Schremmer, 1986). The head capsule measurements indicated no difference from the actively feeding 6th instar. Microscopic examination, however, revealed that a moult had occurred (Figure 2). Thus, the dark wandering larvae from the last two days of our experiment 
(days 16-17) were separate 7th instar larvae. Although no significant difference was seen between the head capsule widths of the 6th instar and the 7th instar (Figure 1), their head capsules were found to have different morphological characteristics (Figure 2). The 6th instar larvae have functional mouthparts, while the 7th instar larvae have reduced mouthparts. The 7 th instar also has a different form of the head, the eyes are more prominent, and the top of the head is bent down. It is used during forward movement as a hook to fix the head into the substrate, when the larva is moving forward by body contraction. The last instar larvae are wandering about for some time to find an acceptable place for pupation; soon they become immovable and the skin hardens to form a puparium. This larval development in H. illucens was previously described by Schremmer (1986).

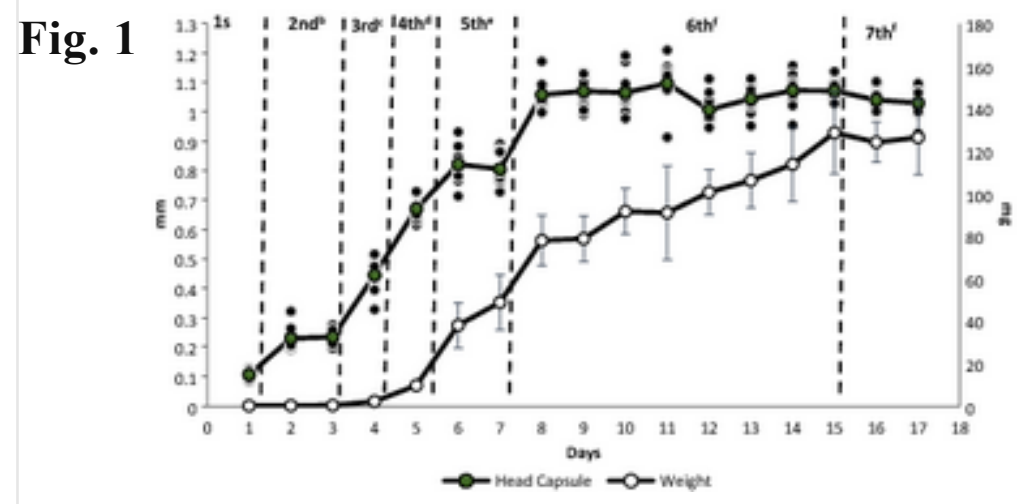

Growth in head capsule width ( $\mathrm{mm}$ ) and mass (mg) of Hermetia illucens larvae measured daily (mean $\pm S D$ ). Larval instars $1-6$ are delimited by vertical dotted lines based on statistical analysis of head capsule widths (indicated by different superscript letters in upper horizontal row). The 7th larval instar was separated based on observation of a moult (Figure 2)

Fig. 2
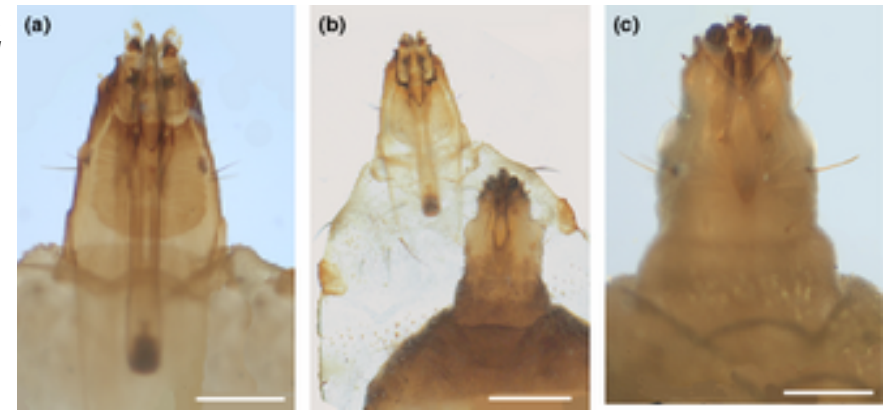

(a) Anterior end of the 6th larval instar of Hermetia illucens larva (Scale: $0.5 \mathrm{~mm}$ ).

(b) Ecdysis process observed between the 6th and 7th instars where the 7th instar is seen inside the exuvia of the 6th larval instar (Scale: $1 \mathrm{~mm}$ ). (c) Anterior end of the 7th larval instar (Scale: $0.5 \mathrm{~mm}$ )

The larvae showed very fast development during most of the actively feeding stadia until they became 6th instars (Figure 1). Thus, the larvae hatching from 
the eggs (first instar) became second instar larvae in less than $24 \mathrm{hr}$. They stayed in the second stadium for two days. From this stage, an even faster development occurred, as the third and fourth stadia lasted only one day each. After that the larvae remained in the fifth stadium for two days. During the 6th stadium, they then spent eight days as actively feeding larvae before moulting into the 7th stadium. The growth in larval body mass followed an S-shaped curve with accelerating growth during stadium $1-5$ and decelerating growth during stadium 5-6 $\left(F_{4}=418.8, p<0.001\right)$. The lack of feeding by the 7 th instar larvae is witnessed by a constant body mass since the end of the 6th stadium (Figure 1).

The SMR was similar across the earlier larval instars (3rd, 4th and 5th) but significantly reduced by the 6 th and even more so by the 7 th instar larvae $\left(F_{4}=39.2, p<0.001\right.$; Figure 3$)$.

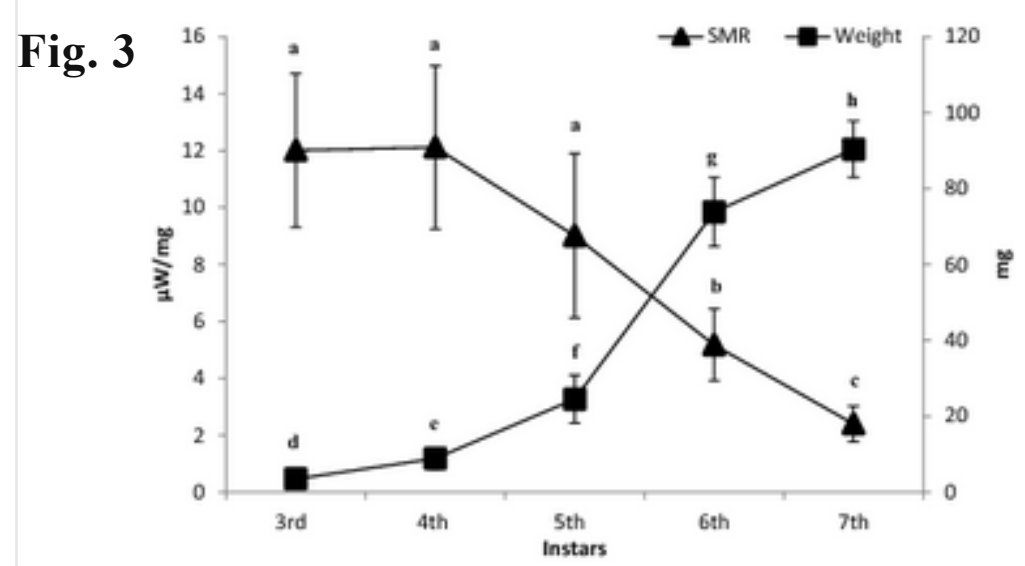

Specific metabolic rate (SMR) and body mass of the Hermetia illucens larvae used for metabolic measurements (mean $\pm S D$ ). Points with the same letter are not significantly different (GLM test, $\alpha<0.05$, followed by Tukey's post hoc test for multiple comparisons). The increase in body mass between the 6th actively feeding instar and the 7th instar in Figure 3 is because the 6th instar larvae were measured just after they entered this instar, cf. Figure 1

\section{DISCUSSION}

The results on head capsule widths (Figure 1) and of the microscopic examinations (Figure 2) show that $H$. illucens passes through six actively feeding stadia before entering the 7 th non-feeding stadium. Our results thus confirm those of Schremmer (1986) who found that the last actively feeding larval instar (the 6th instar) and the 7th instar have different morphological characteristics and are separated by a moult, thus making them two different larval instars. Previously, May (1961) claimed that $H$. illucens larvae pass through only five actively feeding stadia before entering the non-feeding "prepupal" 6th stadium. However, comparison of May's head capsule measurements (May, 1961 table 1) with ours (Figure 1) indicates that she may have missed the first instar, which is very small and of short duration; the exuviae may be easily overlooked. Like Schremmer (1986), May (1961) also reports the occurrence of 
a moult between her 5th instar and the "pre-pupal" instar. Also, the results of Kim et al. (2010) differ from ours, as they claim that H. illucens larvae have six stadia before pupation. Their measurements of actively feeding instars 1-6 are similar to ours, but there is no mention of the non-feeding migratory larval instar. However, the "pupa" measured by Kim et al. (2010 table 1) must be this instar, that is identical with our 7th instar and with May's pre-pupa. In fact, it is the exuvia of the pre-pupa that forms the puparium in H. illucens (see May, 1961 figs 6-7). Thus, the results of all four studies may converge on the agreement that $H$. illucens has seven larval stadia with six actively feeding and growing instars and one non-feeding migratory instar that pupates within its exuvia.

Contrary to the fast development seen in the present paper (17 days for full larval development), Kim et al. (2010) found that $H$. illucens experienced a considerably slower development (28 days) despite being maintained at similar temperatures $\left(27^{\circ} \mathrm{C}\right.$ in $\mathrm{Kim}$ et al., 2010). Furthermore, the body masses of larval instars $(3 \mathrm{rd}=3.9,4$ th $=22.1,5$ th $=66.3$ and 6 th $=185.3 \mathrm{mg} /$ larva $)$ obtained by Kim et al. (2010) were higher than ours. Such differences may be explained by the different methods and dietary regimes used in the two studies as well as due to different handling. Thus, in the present investigation, the larvae were sampled daily, while May (1961) and Kim et al. (2010) sampled exuviae after each moulting episode. Harnden and Tomberlin (2016) found that different diets (Pork, Beef and Gainesville) affect the development and the mass of different larval instars. However, it is not fully understood to what extent different handling procedures and diet qualities impact the development and body mass of $H$. illucens larvae; this could therefore represent an important topic for further research.

The body mass of the larvae was found to follow a sigmoid curve with accelerating growth in the first five instars and decelerating growth in the sixth instar. Scriber and Slansky (1981) describes that in general, the greatest overall growth and food consumption usually take place in the penultimate and final larval stadia. This pattern is believed to be related to differences in energy allocation and metabolism during the earlier and the later stadia. In the earlier stadia, the larvae are mainly focusing on rapid development and primarily allocate energy to catabolism, which leads to high metabolic rates. In H. illucens, however, after reaching a certain size (instar 4, Figure 1), the metabolic rate decreases (Figure 3), as the larvae increasingly focus on building body mass and storing the energy reserves (anabolism) required for metamorphosis and for reproduction in the adult life stage (Schmolz \& Lamprecht, 2000). The results obtained from the calorimetric measurements of H. illucens larvae support these arguments. Thus, the SMR of H. illucens larvae decreased with increasing mass and development stage (Figure 3). Acar, Mill, Smith, Hansen, and Booth (2004) found that the specific metabolic rate of lady beetles (Harmonia axyridis (Pallas, 1773)) decreased with increasing larval development stage, and Schmolz, Kösece, and Lamprecht (2005) obtained similar results for European honeybee drones (Apis mellifera Linnaeus, 1758). 
As a step towards implementing H. illucens in bioconversion systems, it would be an advantage to predict the waste conversion efficiency depending on waste composition and conversion efficiencies under various temperature regimes. Such predictions can be made by aid of simulation modelling. Simulation modelling is no magic tool, but requires a detailed knowledge of essential biological processes such as the temperature-dependent larval growth and larval waste conversion efficiency. A full understanding of these processes under a wide range of environmental circumstances will provide the knowledge necessary to develop simulation models of their population development and of the amount of waste they consume. A metabolic pool model (Gutierrez, 1996) seems to be a good choice of model type for this purpose, as this kind of model is ideal for simulating predator-prey interactions, and it can be programmed to take different temperature regimes into account through the utilization of a physiological time scale as defined by the degree-day concept or the Gauss equation (Taylor, 1981). In the case of black soldier flies, the predator will be the soldier fly and the prey will be the waste or different types of waste. The results concerning the growth of $H$. illucens larvae are challenging for a detailed modelling of their growth, and in turn for their conversion efficiency of waste, as they show a rather constant growth measured in grams per day, but a decreasing relative growth rate (measured in $\mathrm{g} / \mathrm{g} / \mathrm{day}$ ) in 5 th and especially 6 th instar. Most often models use a specific growth rate in units of $\mathrm{g} / \mathrm{g} / \mathrm{time}$ for the entire juvenile stage (Gutierrez, 1996) or at least for each instar (Axelsen, 2009). Looking at the growth curve of 5th and 6th instars, it is clear that the massdependent growth rate is decreasing as the growth is not exponential. Therefore, the results from this investigation will make it necessary to make the growth rate mass or age specific, which will be new to most population dynamical model types.

\section{CONCLUSION}

The results presented here confirms that $H$. illucens larvae pass through six actively feeding stadia followed by a separate migratory 7 th stadium (pre-pupa) as previously described by Schremmer (1986). The first six instars can be easily identified using head capsule width measurements while the 7 th instar can be distinguished from the 6th instar by differences in morphological characteristics as well as colour and behaviour. Furthermore, larval metabolism decreased as a function of increasing larval body mass and larval instar number. The results regarding larval growth are important for population dynamical modelling, as the growth rates of the actively feeding 5 th and 6 th instars are not constant.

\section{ACKNOWLEDGEMENTS}

We thank two anonymous reviewers for valuable comments.

\section{AUTHOR CONTRIBUTION}

Author AG, ST and SAN conceived and designed research. AG, ST and SAN wrote the paper. AG, ST and SAN analysed data and conducted statistical 
analysis. JAaA and HHN contributed material. All the authors read and approved the final manuscript.

\section{REFERENCES}

Acar, E. B., Mill, D. D., Smith, B. N., Hansen, L. D., \& Booth, G. M. (2004). Calorespirometric determination of the effects of temperature on metabolism of Harmonia axyridis (Col: Coccinellidae) from second instars to adults. Environmental Entomology, 33(4), 832-838. https://doi.org/10.1603/0046$225 \mathrm{X}-33.4 .832$

Axelsen, J. A. (2009). Simulation studies of Senegalese Grasshopper ecosystem interactions I: The ecosystem model. International Journal of Pest Management, 55, 85-97. https://doi.org/10.1080/09670870802601084

Barragan-Fonseca, K. B., Dicke, M., \& vanLoon, J. J. A. (2017). Nutritional value of the black soldier fly (Hermetia illucens L.) and its suitability as animal feed - A review. Journal of Insects as Food and Feed, 3(2), 105-120. https://doi.org/10.3920/JIFF2016.0055

Benelli, G., Canale, A., Raspi, A., \& Fornaciari, G. (2014). The death scenario of an Italian Renaissance princess can shed light on zoological dilemma: Did the black soldier fly reach Europe with Columbus? Journal of Archaeological Science, 49, 203-205. https://doi.org/10.1016/j.jas.2014.05.015

Cummins Jr, V. C., Rawles, S. D., Thompson, K. R., Velasquez, A., Kobayashi, Y., Hager, J., \& Webster, C. D. (2017). Evaluation of black soldier fly (Hermetia illucens) larvaemeal as partial or total replacement of marine fish meal in practical diets for Pacific white shrimp (Litopenaeus vannamei). Aquaculture, 473, 337-344. https://doi.org/10.1016/j.aquaculture.2017.02.022

Diclaro II, J. W., \& Kaufman, P. E. (2009). Black Soldier Fly Hermetia illucens Linnaeus (Insecta: Diptera: Stratiomyidae). IFAS Extension: University of Florida. Retrieved from http://edis.ifas.ufl.edu/pdffiles/in/in83000.pdf

Diener, S., Zurbrugg, C., \& Tockner, K. (2009). Conversion of organic material by black soldier fly larvae: Establishing optimal feeding rates. Waste Management and Research, 27, 603-610. https://doi.org/10.1177/0734242X09103838

Eurostat (2016). Agricultural products, meat and milk. Retrieved from http://ec.europa.eu/eurostat/statisticsexplained/index.php/AgriculturalproductsMeatan

FAO (2009). How to feed the World 2050, Global agriculture towards 2050.

Rome, Italy: FAO. Retrieved from

http://www.fao.org/fileadmin/templates/wsfs/docs/expert_paper/HowtoFeedtheWorldi 
Gobbi, P., Martinez-Sanchez, A., \& Rojo, S. (2013). The effects of larval diet on adult life-history traits of the black soldier fly, Hermetia illucens (Diptera: Stratiomyidae). European Journal of Entomology, 110(3), 461. https://doi.org/10.14411/eje.2013.061

Gutierrez, A. P. (1996). Applied population ecology. A supply - Demand approach. New York, NY: John Wiley \& Sons Inc.

Hale, O. M. (1973). Dried Hermetia illucens larvae (Diptera: Stratiomyidae) as a feed additive for poultry. Journal of Georgia Entomology Society, 8, 16-20. https://doi.org/10.2527/jas 1977.443395x

Hall, R. D., \& Gerhardt, R. R. (2002). Flies (Diptera). In G. L. Mullen, \& A. L. Durden (Eds.), Medical and veterinary entomology (pp. 127-145). Burlington, MA: Academic Press Publisher.

Harnden, L. M., \& Tomberlin, J. K. (2016). Effects of temperature and diet on black soldier fly, Hermetia illucens (L.) (Diptera: Stratiomyidae), development. Forensic Science International, 266, 109-116.

https://doi.org/10.1016/j.forsciint.2016.05.007

Kim, W., Bae, S., Park, H., Park, K., Lee, S., Choi, Y., ... Koh, Y. (2010). The larval age and mouth morphology of the black soldier fly, Hermetia illucens (Diptera: Stratiomyidae). International Journal of Industrial Entomology, 21, 185-187. https://doi.org/10.5656/KSAE.2008.47.4.337

Lalander, C. H., Fidjeland, J., Diener, S., Eriksson, S., \& Vinnerås, B. (2015). High waste-to-biomass conversion and efficient Salmonella spp. reduction using black soldier fly for waste recycling. Agronomy for Sustainable Development, 35, 261-271. https://doi.org/10.1007/s13593-014-0235-4

Magalhães, R., Sánchez-López, A., Silva Leal, R., Martínez-Llorens, S., OlivaTeles, A., \& Peres, H. (2017). Black soldier fly (Hermetia illucens) pre-pupae meal as a fish meal replacement in diets for European seabass (Dicentrarchus labrax). Aquaculture, 476, 79-85.

https://doi.org/10.1016/j.aquaculture.2017.04.021

Marshall, S. A., Woodley, N. E., \& Hauser, M. (2015). The Historical spread of the Black Soldier Fly. Hermitia illucens (L.) (Diptera, Stratiomyidae, Hermetiinae), and its establishment in Canada. Journal of the Entomological Society of Ontario, 146, 51-54.

May, B. M. (1961). The occurrence in New Zealand and the life-history of the black soldier fly Hermetia illucens (L.) (Diptera: Stratiomyidae). New Zealand Journal of Science, 4, 55-65. 
Newton, G. L., Booram, C. V., Barker, R. W., \& Hale, O. M. (1977). Dried Hermetia illucens Larvae meal as a supplement for swine. Journal of Animal Science, 44(3), 395-400. https://doi.org/10.2527/jas1977.443395x

Newton, L., Sheppard, C., Watson, D. W., Burtle, G., \& Dove, R. (2005). Using the black soldier fly, Hermetia illucens, as a value added tool for the management of swine manure. Raleigh, NC: North Carolina State University. Retrieved from http://www.organicvaluerecovery.com/studies/studies_htm_files/bsf_value_added.pdf

Nguyen, T. T. X., Tomberlin, J. K., \& Van Laerhoven, S. (2013). Influence of resources on Hermetia illucens (Diptera: Stratiomyidae) larval development. Journal of Medical Entomology, 50, 898-906. https://doi.org/10.1603/ME12260

Nielsen, S. A., Jensen, K.-M.- V., Kristensen, M., \& Westh, P. (2006). Energetic cost of subacute chlorpyrios intoxication in the German Cockroach (Dictyoptera: Blattellidae). Environmental Entomology, 35, 837-842. https://doi.org/10.1603/0046-225X-35.4.837

Oliveira, F. R., Doelle, K., \& Smith, R. P. (2016). External morphology of Hermetia illucens Stratiomyidae: Diptera (L.1758) based on electron microscopy. Annual Research \& Review in Biology, 9(5), 1-10. https://doi.org/10.9734/arrb/2016/22973

Pujol-Luz, J. R., Pitaluga De Godoi, F. S., \& Barros-Cordeiro, K. B. (2016). Description of the puparium of Hermetia pulchra (Diptera: Stratiomyidae) from Brazil. Zootaxa, 4250(4), 357-364. https://doi.org/10.11646/zootaxa.4205.4.4

Roháček, J., \& Hora, M. (2013). A northernmost European record of the alien black soldier fly Hermetia illucens (Linnaeus, 1758) (Diptera: Stratiomyidae). Časopis Slezské Zemské Muzeum, Série A, 62, 101-106. https://doi.org/10.2478/cszma-2013-0011

Schmolz, E., Kösece, F., \& Lamprecht, I. (2005). Energetics of honeybee development Isoperibol and combustion calorimetric investigations. Thermochimica Acta, 437, 39-47. https://doi.org/10.1016/j.tca.2005.06.001

Schmolz, E., \& Lamprecht, I. (2000). Calorimetric investigations on activity states and development of holometabolous insects. Thermochimica Acta, 349, 61-68. https://doi.org/10.1016/S0040-6031(99)00497-9

Schremmer, V. F. (1986). Die polymetabole Larval-Entwicklung der Waffenfliegenart Hermetia illucens. - Ein Beitrag zur Metamorphose der Stratiomyidae. Annalen Des Naturhistorisches Museums in Wien, 88-89B, 405429. 
Scriber, J. M., \& Slansky Jr, F. (1981). The nutritional ecology of immature insects. Annual Review of Entomology, 26, 183-211. https://doi.org/10.1146/annurev.en.26.010181.001151

Sheppard, D. C., Newton, G. L., Thompson, S. A., \& Savage, S. (1994). A value added manure management system using the black soldier fly. Bioresource Technology, 50, 275-279. https://doi.org/10.1016/0960-8524(94)90102-3

Speedy, W. A. (2004). Overview of world feed protein needs and supply. In FAO (Ed.), Protein sources for the animal feed industry (pp. 9-27). Rome, Italy: FAO. Retrieved from http://www.fao.org/docrep/007/y5019e/y5019e05.htm\#bm05

St-Hilaire, S., Sheppard, C., Tomberlin, J. K., Irving, S., Newton, L., McGuire, M. A., ... Sealey, W. (2007). Fly prepupae as a feedstuff for rainbow trout, Oncorhynchus mykiss. Journal of the World Aquaculture Society, 38, 59-67. https://doi.org/10.1111/j.1749-7345.2006.00073.x

Taylor, F. (1981). Ecology and evolution of physiological time in insects. The American Naturalist, 117(1), 1-23. https://doi.org/10.1086/283683

Tomberlin, J. K., Adler, P. H., \& Myers, H. M. (2009). Development of the black soldier fly (Diptera: Stratiomyidae) in relation to temperature.

Environmental Entomology, 38, 930-934. https://doi.org/10.1603/022.038.0347

Tomberlin, K. J., Sheppard, D. C., \& Joyce, J. A. (2002). Selected life-history traits of black soldier flies (Diptera: Stratiomyidae) reared on three artificial diets. Annals of the Entomological Society of America, 95, 379-386.

van Huis, A., van Itterbeeck, J., Klunder, H., Mertens, E., Halloran, A., Muir, G., \& Vantomme, P. (2013). Edible insects - Future prospects for food and feed security. FAO Forestry Paper 171. Retrieved from http://www.fao.org/docrep/018/i3253e/i3253e00.htm 